\title{
Phosphorus Response and Fertilizer Recommendations under Balanced Fertilizers for Tef (Eragrostis tef) Grown on Vertisol in the Central Highlands of Ethiopia
}

\author{
Girma Chala* Kebede Dinkecha Zeleke Obsa \\ Holeta Agricultural Research Center, Ethiopian Institute of Agricultural Research, EIAR P.O. Box 2003, Addis \\ Ababa, Ethiopia
}

\begin{abstract}
Phosphorous response and fertilizer recommendation under balanced fertilizer study was conducted for tef grown on Vertisols in Dendi district, West Shewa, in central highlands of Ethiopia. The experiment was arranged in a complete block design with six levels of phosphorous fertilizer $\left(0,10,20,30\right.$ and $\left.40 \mathrm{~kg} \mathrm{ha}^{-1}\right)$ with three replications. Based on a yield difference between the control and the $\mathrm{P}$ treatments, $80 \%$ of sites responded to $\mathrm{P}$ fertilizer. The application of phosphorous fertilizer at different rates increased grain yield of tef, up to $13.6 \%$ as compared to the control (zero p treatment). Extractable soil P concentrations (Olsen method, 0- $20 \mathrm{~cm}$ depth) three weeks after planting significantly responded to $\mathrm{P}$ fertilizer rate. Correlations of relative yield soil phosphorous values showed that the soil phosphorous levels greater than $15.6 \mathrm{mg} \mathrm{kg}^{-1}$ (critical phosphorous concentration) was found to be sufficient for tef production. The average phosphorous requirement factor $(\mathrm{Pf})$ calculated from soil phosphorous values of all treatments for the study area was 12.6. In the absence of a soil test, a recommendation of $30 \mathrm{~kg} \mathrm{P}^{-}$ ${ }^{1}$ to prevent a potential loss of tef. Further field trials are required to determine interactions between $P$ response and the effects of climate, soil properties, and other management practices.
\end{abstract}

Keywords: Critical P concentration, Phosphorus, Relative yield, Tef, Vertisol

DOI: $10.7176 / \mathrm{JNSR} / 11-20-01$

Publication date:October $31^{\text {st }} 2020$

\section{INTRODUCTION}

Soil fertility is considered to be the major constraint in the highlands of Ethiopia due to continuous cultivation of these soils without adequate replenishment of nutrients for long years. This made highland soils deficient in nutrients particularly nitrogen $(\mathrm{N})$ and phosphorous $(\mathrm{P})$ [1]. Several studies have indicated widespread nutrients mining both in quality and quantity as compared to their replenishments either from natural or anthropogenic inputs, resulting in a negative nutrient balance in Africa [2]; [3]; [4]. Hence, leading to severe nutrient deficiencies across ecological zones and consequently reducing agricultural productivity. The recent soil fertility map of Ethiopia shows deficiency of $86 \% \mathrm{~N}, 99 \% \mathrm{P}, 7 \% \mathrm{~K}, 92 \% \mathrm{~S}, 65 \% \mathrm{~B}$ and $53 \% \mathrm{Zn}$ [5]. In Ethiopia, low-input agricultural production systems and poor agronomic management practices, limited awareness of communities and absence of proper land-use policies have aggravated soil fertility degradation [6].

Tef [Eragrostis tef (Zucc.) Trotter] has traditionally been an important cereal in Ethiopia, it has also recently received global attention particularly as a 'healthy food' due to the absence of gluten and gluten-like proteins in its grains [7]. In Ethiopia, tef is the first cereal crop in area coverage followed by maize, with an estimated area of 3.02 million ha of land, but ranks second after maize in production of 5.28 million tons per year [8]. Tef is grown under diverse agro-climatic zones and altitudes of $1800-2100 \mathrm{~m}$ a s 1 , annual rainfall of $750-1100 \mathrm{~mm}$ and a temperature of $10^{\circ} \mathrm{C}-27^{\circ} \mathrm{C}$ [9]. Moderately fertile clay and clay loam soils are ideal for tef. It can also withstand moderate water logged conditions [10]. Regardless of its wider adaptation, productivity of tef is low in the country with the national average grain yield of 1.379 tons $\mathrm{ha}^{-1}[8]$. This is mainly because of low soil fertility [11] and severe organic matter depletion [12]. This is aggravated by low rate of chemical fertilizer application, in which its rate of application is low in the country due to cost and logistic problem for resource-poor smallholder farmers [13].

Phosphorous is the most yield limiting nutrient, and soil $\mathrm{P}$ tends to decline when soils are extensively used for agriculture [14]. Most Ethiopian soils including Vertisol are deficient in P when assayed by chemical methods; yet, with the addition of $\mathrm{P}$ fertilizers, field crop $\mathrm{P}$ responses on these soils, particularly in the central highlands are low, even under improved drainage conditions [15]. Several possible chemical and biological theories may be given for the poor response to $\mathrm{P}$ fertilizer, but this may be beyond the scope of this paper. Moreover, the nutrients in the blanket recommendation are not well balanced agronomical and its continued use will gradually exhaust soil nutrient reserves. As crop response declined with widespread deficiencies of nutrients other than $\mathrm{N}$ and $\mathrm{P}$, farmers are discouraged to apply these fertilizer recommendations. At present, N, P, S, boron (B) and zinc (Zn) deficiencies are widespread in Ethiopian soils, while some soils are also deficient in $\mathrm{K}$, copper $(\mathrm{Cu})$, manganese $(\mathrm{Mn})$ and iron (Fe) [16]; [5]. Responses of tef to $\mathrm{N}$ and $\mathrm{P}$ have been documented in tef growing areas of Ethiopia but little has been done to establish the scale of macro (N, P K and S) and micronutrient (Zn, B) deficiencies. 
Calibration is a means of establishing a relationship between a given soil test value and the yield response from adding nutrient to the soil as fertilizer. It provides information how much nutrient should be applied at a particular soil test value to optimize crop growth without excessive and confirm the validity of current $\mathrm{P}$ recommendations [17], [18]. They enable to revise fertilizer recommendations for an area based on soil and crop type, $\mathrm{pH}$ and soil moisture content at time of planting. An accurate soil test interpretation requires knowledge of the relationship between the amount of a nutrient extracted by a given soil test and the amount of plant nutrients that should be added to achieve optimum yield for a particular crop [19]; [20].

Soil tests are designed to help farmers predict the available nutrient status of their soils. Once the existing nutrient levels are established, producers can use the data to best manage what nutrients are applied, decide the application rate and make decisions concerning the profitability of their operations [21]. However, local assessments for the soil P critical levels and soil P requirement factors even for the major crops of the country are negligible. However, the right rate of recommended fertilizer for the specific soil, ecology and crop type is important. Very recently soil fertility research improvement started site specific fertilizer application in the country and instead of DAP and Urea, location specific blended fertilizer shall be distributed to smallholder farmers. Therefore, the objectives of this study were to investigate the association between the Olsen method- P content of the soil with the relative grain yield response of tef grown on vertisols of west shewa, Ethiopia.

\section{MATERIALS AND METHODS}

\subsection{Description of the Study Site}

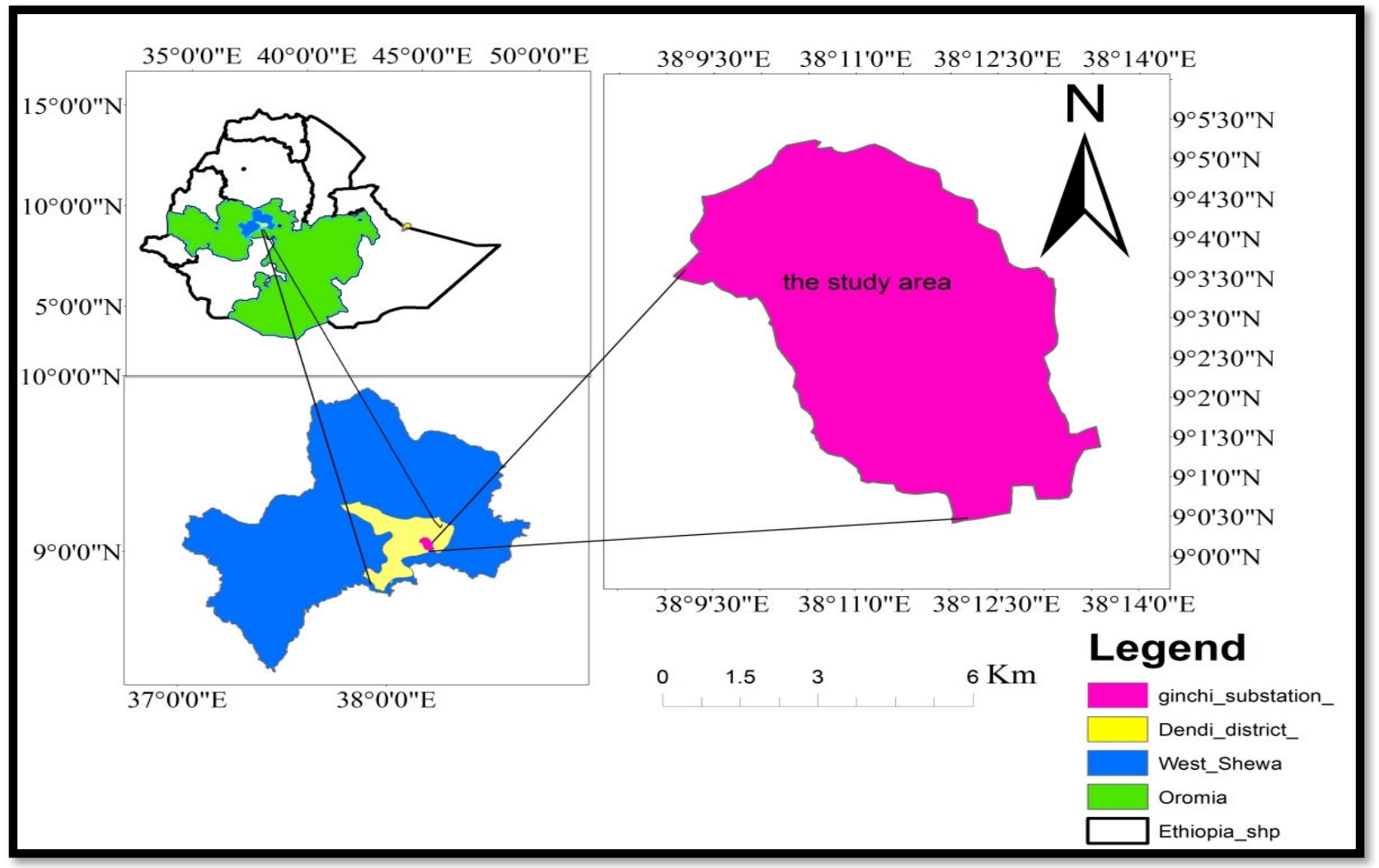

\section{2: Experimental Site}

A phosphorus response trial with tef was conducted on permanent fields in 2017 during the main cropping seasons in West Shewa, at Dendi wareda on vertisols. The experimental site is located at $09002^{\prime} \mathrm{N}$ and $38012^{\prime} \mathrm{E}$ and an altitude of 2200 masl at a road distance of about $74 \mathrm{~km}$ West of Addis Ababa. The area is characterized by a unimodal rainfall pattern and receives an average annual rainfall of $1080 \mathrm{~mm}$, about $85 \%$ of which is received from June to September. The total cultivated land is estimated to be 27,583 ha out of which $25,476.8$ ha is cultivated rain-fed while 2,106.2 ha are irrigated.

The soil of the area is characteristically vertisols, which is black in colour and clay in texture and its $\mathrm{pH}$ ranges 5.8 to 7.2. The dominant crops produced in the district are mostly cereals, pulses, oil seeds and vegetable crops (unpublished data).

Soil sampling three week after planting was taken from each plot an auger was used to sample five randomly selected spots per plot. These five subsample soils combined into one composite soil sample per each plot for 
investigating soil properties of each treatment. The collected soil samples were bagged, labeled and transported to the laboratory for preparation and analysis of soil properties. Sufficient amount of composite soil samples were air dried and ground to pass through a $2 \mathrm{~mm}$ sieve in preparation for the analyses of the selected physicochemical properties following standard laboratory procedures [22].The collected samples were analyzed for the determinations of $\mathrm{pH}$, organic carbon $(\mathrm{OC})$, total $\mathrm{N}$ and available $\mathrm{P}$ and $\mathrm{CEC}$. Soil $\mathrm{pH}$ was determined with a $\mathrm{pH}$ electrode at soil: water of 1:1 (w/v) [23]. Organic carbon was determined by the method of [24] and total $\mathrm{N}$ using Kjeldahl method [25]. Available P was determined following the procedures of [26], exchangeable cations and cation exchange capacity (CEC) using ammonium acetate method at Holeta Agricultural Research Center. The available soil $\mathrm{P}$ (using Olsen method) ranges prior to planting considered for classification were $<10 \mathrm{mg} \mathrm{P} \mathrm{kg}^{-1}$ for low, 10-25 mg P kg-1 for medium, and $>25 \mathrm{mg} \mathrm{P} \mathrm{kg}^{-1}$ for high. Based on this categorization, an experimental field was created in four gradient groups with low $\mathrm{P}$, medium $\mathrm{P}$ and high phosphorus fields.

\section{3: Experimental Procedures}

The experiment was arranged in randomized complete block design with five levels of phosphorus $(0,10,20,30$ and $40 \mathrm{~kg} \mathrm{P} \mathrm{ha}{ }^{-1}$ ) and replicated three times. On the first year the field was grown maize for exhaustive trial without fertilizers and at second year a field was divided into 4 strips, which was 4 doses of Phosphorus such as $\left(\mathrm{P}_{0} \mathrm{~N}_{1} \mathrm{~S}_{1} \mathrm{~B}_{1}\right.$, $\mathrm{P}_{1 / 2}+\left(\mathrm{N}_{1} \mathrm{~S}_{1} \mathrm{~B}_{1}\right), \mathrm{P}_{1}+\left(\mathrm{N}_{1} \mathrm{~S}_{1} \mathrm{~B}_{1}\right)$ and $\mathrm{P}_{2}+\left(\mathrm{N}_{1} \mathrm{~S}_{1} \mathrm{~B}_{1}\right)$ was conducted. Similarly, on the third year the plots was again follow the same procedure each of the plots divided into 4 strips. Finally on the $4^{\text {th }}$ year the experimental field was $16(4 \times 4)$ and five P levels with three times replication (15) was implemented or conducted on each of the experimental field.so that the total experimental unit(plots) of this trial 240(16 experimental field x 15=240) was accommodated. The experiment was conducted in the same field for four years in order to study the residual effects. The gross plot size was $3 \mathrm{~m} \times 2 \mathrm{~m}\left(6 \mathrm{~m}^{2}\right)$ and accommodating a minimum of 15 rows per plot. The net plot size was determined with area and plant density leaving the one outermost row and sides of each row the spacing between blocks, plots and rows were $1 \mathrm{~m}, 0.5 \mathrm{~m}$ and $0.2 \mathrm{~m}$, respectively. The harvested plot area measured $4 \mathrm{~m}^{2}$. The sources of $\mathrm{N}$ and $\mathrm{P}$ were urea and triple super-phosphate (TSP), respectively. However, a research recommendation of N and P fertilizer (69-60-0 $\mathrm{kg}$ NPK ha $\left.\mathrm{h}^{-1}\right)$ in the form of urea and DAP have been used for tef on vertisol area in Ethiopia. Plant height was measured from the ground level to the tip of the panicle at physical maturity. Panicle length (PL in $\mathrm{cm}$ ) was measured from the base to the top of the panicle and to measure total biomass and grain yields, the entire plot was harvested at maturity in December. After threshing, the seeds were cleaned and weighed and the moisture content was measured. Total biomass (dry matter basis) and grain yields (adjusted to moisture content of $12.5 \%$ ) recorded on plot basis were converted to $\mathrm{kg} \mathrm{ha}^{-1}$ for statistical analysis. The SAS statistical computer package [27]was used to test for presence of outliers and normality of residuals.

Land preparation was done at the end of May in accordance with a standard practice locally used. The experimental plot was cultivated by an oxen-drawn implement to the depth of 25-30 centimetres. The land was levelled and ridges were made manually. Tef (kuncho variety) was planted by using $15 \mathrm{~kg} \mathrm{ha}^{-1}$. Cultivation, weeding, chemical spray and harvesting were done at the appropriate time according to the research recommendations.

Application of phosphorus fertilizer was done by banding the granules of TSP (Triple super-phosphate) at the depth of $5 \mathrm{~cm}$ below at planting. Nitrogen at the rate of $69 \mathrm{~kg} \mathrm{~N} \mathrm{ha}^{-1}$ was applied in the form of urea in two splits $\left(1 / 2^{\text {rd }}\right.$ at planting, $1 / 2^{\text {rd }}$ at mid-stage). Harvesting was done at physiological maturity.

\section{4: Data Collection}

Agronomic parameters collected were plant height and panicle length $(\mathrm{cm})$, was measured by taking five randomly selected plants per plot as the distance in $\mathrm{cm}$ from the soil surface to the top most growth point of aboveground at full maturity. Grain and biomass yield were measured based on plant samples taken from ten central rows $(2 \mathrm{~m} \mathrm{x}$ $2 \mathrm{~m}=4 \mathrm{~m}^{2}$ ) at full maturity stage. Grain yield and biomass yields recorded on plot basis were converted to $\mathrm{kg}^{\mathrm{h}} \mathrm{h}^{-1}$ for statistical analysis.

Determination of critical P concentration $(P c)$ : to correlate relative yield vs soil $\mathrm{P}$ values and determine critical $\mathrm{P}$ concentration, the available $\mathrm{P}$ was extracted from the soil samples taken three weeks after planting from each plot of all experimental fields using Olsen method.

The Cate-Nelson graphical method [28]was determine the critical $\mathrm{P}$ value using relative yields and soil test $\mathrm{P}$ values obtained from $16 \mathrm{P}$ fertilizer trials field conducted at different $\mathrm{P}$ levels $(16 \mathrm{P}$ fertilizer trial field was already mention under experimental procedures). To assess the relationship between grain yield response to nutrient rates and soil test $\mathrm{P}$ values, relative grain yields in percent were calculated as follows:

$$
\text { Relative yield }(\%)=\frac{\text { Yield }}{\text { Maximum yield }} \mathrm{X} 100
$$

The scatter diagram of relative yield ( $\mathrm{y}$-axis) versus soil test values ( $\mathrm{x}$-axis) was plotted. The range in values on the $\mathrm{Y}$-axis was 0 to $100 \%$. A pair of intersecting perpendicular lines was drawn to divide the data into four quadrants. The vertical line defines the responsive and non-responsive ranges. The observations in the upper left 
quadrants overestimate the $\mathrm{P}$ fertilizer $\mathrm{P}$ requirement while the observations in the lower right quadrant underestimate the fertilizer requirement. The intersecting lines were moved about horizontally and vertically on the graph, always with the two lines parallel to the two axes on the graph, until the number of points in the two positive quadrants was at a maximum (or conversely, the number of points in the two negative quadrants was at a minimum). The point where the vertical line crosses the X-axis was defined as optimum critical soil test level [28].

Determination of $P$ requirement factor $\left(\boldsymbol{P}_{f}\right)$ : phosphorus requirement factor $\left(\mathrm{p}_{\mathrm{f}}\right)$ is the amount of $\mathrm{P}$ in $\mathrm{kg}$ needed to raise the soil $\mathrm{P}$ by $1 \mathrm{mg} \mathrm{kg}^{-1}$. It enables to determine the quantity of $\mathrm{P}$ required per hectare to raise the soil test by $1 \mathrm{mg} \mathrm{kg}^{-1}$, and to determine the amount of fertilizer required per hectare to bring the level of available $\mathrm{P}$ above the critical level [29]. Using to calculated available P values in samples collected from unfertilized and fertilized plots on the same treatments result of soil sample was taken after three week become varies, the result put by range from minimum - maximum and used to calculate value of $\mathrm{P}$ increase over the control (table 3). Phosphorous requirement factor was expressed as:

$$
P f=\frac{k g \text { P applied }}{\Delta \text { soil } \mathrm{P}}
$$

Therefore the rate of $\mathrm{P}$ fertilizer to be applied $(\mathrm{Pa})$ was expressed in terms of critical $\mathrm{P}$ concentration $\left(P_{c}\right)$, initial soil $\mathrm{P}$ value $\left(P_{i}\right)$ and $\mathrm{P}$ requirement factor $\left(P_{f}\right)$.

$$
P a=(P c-P i) x P f
$$

\section{5: Statistical Analysis}

The data were subjected to analysis of variance using the procedure of the SAS statistical package version 9.0 [27]. The total variability for each trait was quantified using the following model.

$$
\mathrm{T}_{\mathrm{ijk}}=\mu+\mathrm{Y}_{\mathrm{i}}+\mathrm{R}_{\mathrm{j}(\mathrm{i})}+\mathrm{P}_{\mathrm{k}}+\mathrm{PY}_{(\mathrm{ik})}+\mathrm{e}_{\mathrm{ijk}}
$$

Where $T_{i j k}$ is the total observation, $\mu$ grand mean, $Y_{i}=$ effect of the $i^{\text {th }}$ year, $R_{j(i)}$ is the effect of the $j^{\text {th }}$ replication(with in the $\mathrm{i}^{\text {th }}$ year), $\mathrm{P}_{\mathrm{k}}$ is the effect of the $\mathrm{k}^{\text {th }}$ treatment, $\mathrm{PY}{ }_{(\mathrm{ik})}$ is the interaction of $\mathrm{k}^{\text {th }}$ treatment with $\mathrm{i}^{\text {th }}$ year and $\mathrm{e}_{\mathrm{ijk}}$ is the random error. Means for the main effects were compared using the means statement with the least significant difference (LSD) test at the $5 \%$ level.

\begin{tabular}{|c|c|c|c|c|c|c|c|}
\hline \multirow[t]{2}{*}{ Trial field } & \multirow[t]{2}{*}{$\mathrm{pH}\left(\mathrm{H}_{2} \mathrm{O}\right)$} & \multirow{2}{*}{$\begin{array}{l}\text { Nitrogen } \\
(\%)\end{array}$} & \multirow{2}{*}{$\begin{array}{l}\text { Phosphorus } \\
\text { (ppm) }\end{array}$} & \multirow[t]{2}{*}{$\mathrm{OC}(\%)$} & \multicolumn{3}{|c|}{ Exchangeable cations meq $/ 100 \mathrm{~g}$} \\
\hline & & & & & $\mathrm{Na}$ & $\mathrm{K}$ & CEC \\
\hline 1 & 6.24 & 0.23 & 4.70 & 2.4 & 0.16 & 2.28 & 18.64 \\
\hline 2 & 6.51 & 0.26 & 5.16 & 2.6 & 0.18 & 2.25 & 19.32 \\
\hline 3 & 6.78 & 0.28 & 5.57 & 2.5 & 0.15 & 2.42 & 20.32 \\
\hline 4 & 6.80 & 0.26 & 8.94 & 2.8 & 0.16 & 2.84 & 22.28 \\
\hline Mean & 6.58 & 0.26 & 6.09 & 2.6 & 0.16 & 2.45 & 20.14 \\
\hline
\end{tabular}

\section{RESULTS AND DISCUSSION}

Table1. Soil chemical characteristics of the trial site before application of treatments at HARC

Phosphorus test Olsen method

The statically analysis of tef yield and yield components revealed that significantly $(\mathrm{p}<0.05)$ on plant height, panicle length, grain and biomass yield of tef. Relatively the highest mean of plant height was recorded at application of $20 \mathrm{~kg} \mathrm{P}+60 \mathrm{kgN}+7 \mathrm{kgS}+4.9 \mathrm{~kg}$ Borax but highest panicle length was recorded on $30 \mathrm{~kg} \mathrm{P}+60 \mathrm{kgN}$ $+7 \mathrm{kgS}+4.9 \mathrm{~kg}$ Borax. Similarly, relatively highest grain and biomass yield $\left(2409.8 \mathrm{~kg} \mathrm{ha}^{-1}\right.$ and $\left.11005.2 \mathrm{~kg} \mathrm{ha}^{-1}\right)$ at application of $30 \mathrm{~kg} \mathrm{P}+60 \mathrm{kgN}+7 \mathrm{kgS}+4.9 \mathrm{~kg}$ Borax. The application of $\mathrm{P}$ fertilizer at rates of 10, 20, 30 and 40 $\mathrm{kg} \mathrm{ha}^{-1}$ increased grain yield of tef by $8,9,13$ and $12 \%$, respectively, compared to the control(without $\mathrm{P}$ fertilizer). Grain yield consistently increased as P rate increased but not significantly beyond this rate; a slight decline in yield was even observed at the greatest $P$ rate (Table 2 ).

Table 2: Response of phosphorus fertilizers application on tef yield and yield components

\begin{tabular}{lllll}
\hline Treatments & $\begin{array}{l}\text { Plant } \\
\text { height }(\mathrm{cm})\end{array}$ & $\begin{array}{l}\text { Panicle } \\
\text { length }(\mathrm{cm})\end{array}$ & $\begin{array}{l}\text { Grain yield } \\
(\mathrm{kg} / \mathrm{ha})\end{array}$ & $\begin{array}{l}\text { Biomass } \\
(\mathrm{kg} / \mathrm{ha})\end{array}$ \\
\hline Zero P $+60 \mathrm{kgN}+7 \mathrm{kgS}+4.9 \mathrm{~kg}$ Borax & $118.1^{\mathrm{c}}$ & $41.2^{\mathrm{b}}$ & $2093.2^{\mathrm{b}}$ & $8760.4^{\mathrm{c}}$ \\
$10 \mathrm{~kg} \mathrm{P}+60 \mathrm{kgN}+7 \mathrm{kgS}+4.9 \mathrm{~kg}$ Borax & $123.8^{\mathrm{b}}$ & $42.5^{\mathrm{ab}}$ & $2163.8^{\mathrm{ab}}$ & $9921.9^{\mathrm{b}}$ \\
$20 \mathrm{~kg} \mathrm{P}+60 \mathrm{kgN}+7 \mathrm{kgS}+4.9 \mathrm{~kg}$ Borax & $126.7^{\mathrm{a}}$ & $43.0^{\mathrm{a}}$ & $2276.2^{\mathrm{a}}$ & $10463.5^{\mathrm{ab}}$ \\
$30 \mathrm{~kg} \mathrm{P}+60 \mathrm{kgN}+7 \mathrm{kgS}+4.9 \mathrm{~kg}$ Borax & $126.2^{\mathrm{ab}}$ & $42.1^{\mathrm{ab}}$ & $2409.4^{\mathrm{a}}$ & $11005.6^{\mathrm{a}}$ \\
$40 \mathrm{~kg} \mathrm{P}+60 \mathrm{kgN}+7 \mathrm{kgS}+4.9 \mathrm{~kg}$ Borax & $126.5^{\mathrm{ab}}$ & $43.6^{\mathrm{a}}$ & $2385.6^{\mathrm{a}}$ & $10854.2^{\mathrm{ab}}$ \\
\hline LSD $(5 \%)$ & 2.76 & 1.7 & 130.4 & 571.1 \\
CV $(\%)$ & $\mathbf{5 . 5}$ & $\mathbf{9 . 8}$ & $\mathbf{1 4 . 3}$ & $\mathbf{1 3 . 9}$ \\
\hline
\end{tabular}

Within each column, means with different letters are significantly different at $p<0.05$; CV, coefficient of 
variation

Correlation is important to study the relationship between grain yield and plant nutrition as it gives an insight into how different soil properties affect the grain yield of crops. This, in turn, may also help in taking the suitable $\mathrm{P}$ fertilizer management practices so that plants are optimally nourished with respect to the phosphorus. In the present study, positive and highly significant correlation value was observed between grain yield and phosphorus fertilizer $\left(\mathrm{R}=0.9161^{* * *}\right)$ figure 2 . Similar relationship have been observed by [30]in the Vertisol of Maharashtra.

Figure 2. Response curve of Tef grain yield to increasing levels of phosphorus fertilizer

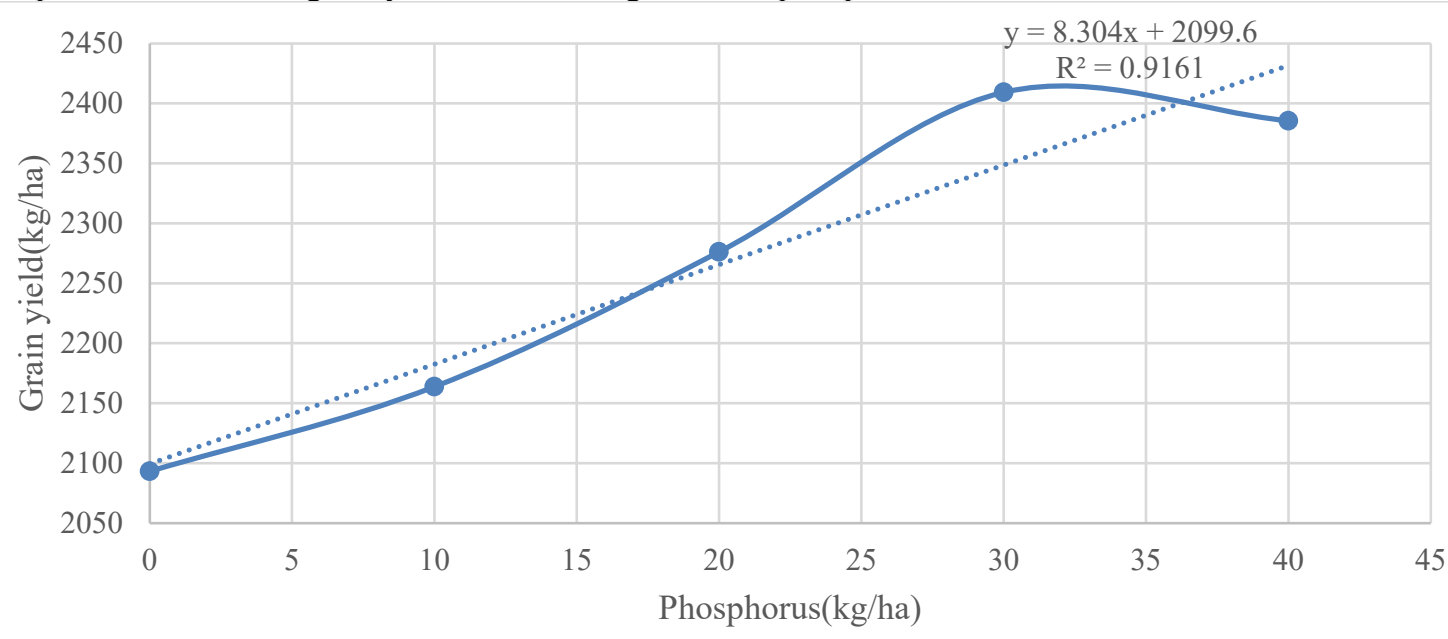

Critical $P$ concentration $(P c)$ and $P$ requirement factor $(P f)$

Soil $\mathrm{P}$ values determined three weeks after planting differed significantly $(P \leq 0.01)$ among $\mathrm{P}$ levels. The main effect of $P$ fertilizer treatments resulted in mean soil test $P$ values 13.6 to $16.8 \mathrm{mg} \mathrm{kg}^{-1}$ (Table 3). Olsen method soil test $\mathrm{P}$ values below $10 \mathrm{mg} \mathrm{kg}^{-1}$ are considered low. Increase in soil $\mathrm{P}$ content in response to $\mathrm{P}$ fertilizer application up to $30 \mathrm{~kg} \mathrm{P} \mathrm{ha}^{-1}$ but showed slight decrease beyond $40 \mathrm{~kg} \mathrm{P} \mathrm{ha}^{-1}$. The highest mean soil $\mathrm{P}$ concentration $(15.6 \mathrm{mg}$ $\mathrm{kg}^{-1}$ ) was recorded from $40 \mathrm{~kg} \mathrm{P} \mathrm{ha-1}$ (Table 3).

Phosphorous critical concentration

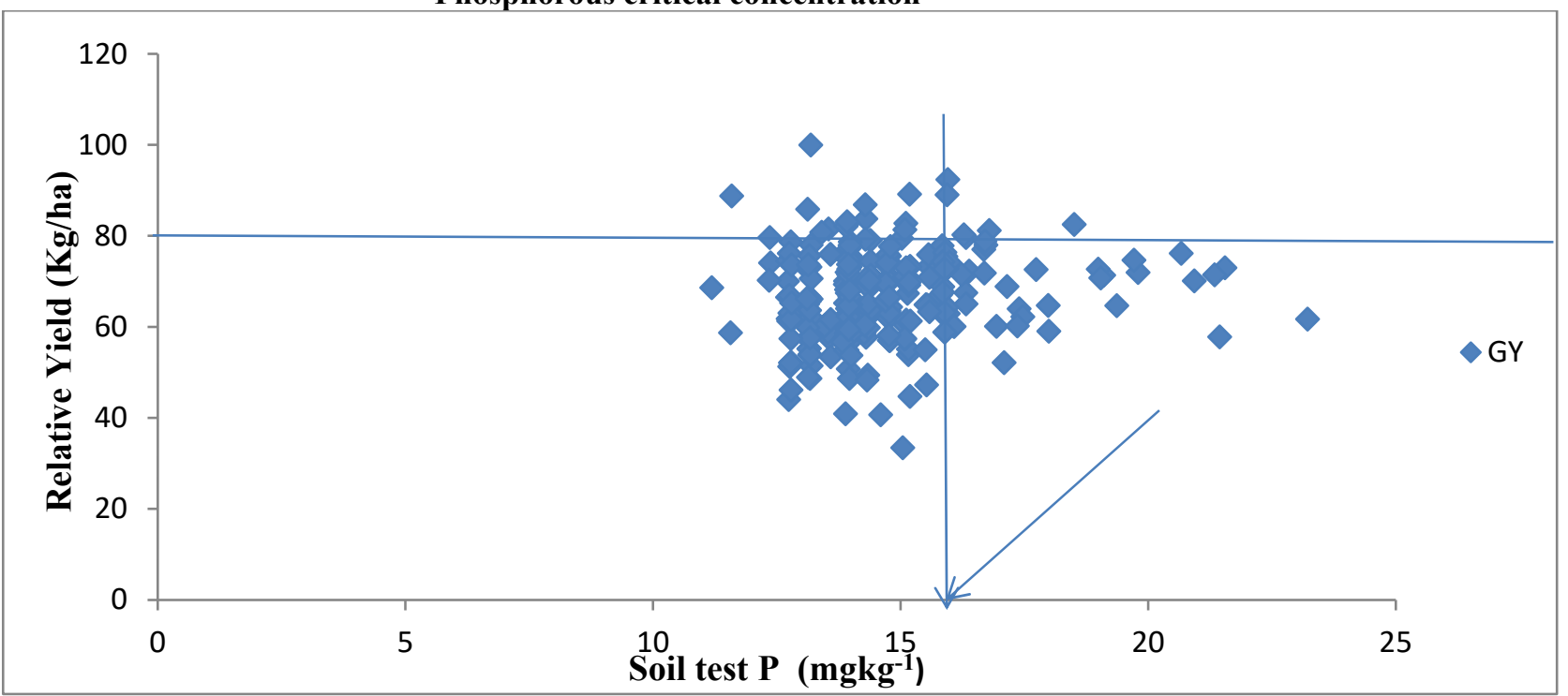

Figure 1: Relationships between relative yield response of tef and soil-test $P$ measured using Olsen method. The arrow indicates the critical $P$ concentration $\left(P_{c}\right)$ for tef on vertisols. 
Table 3: Determination of $P$ requirement factor for tef on vertisols

\begin{tabular}{clllll}
\hline $\begin{array}{c}\text { Phosphorous } \\
\text { rate(kg/ha) }\end{array}$ & Soil test $\mathbf{P}($ Olsen) & Average & $\begin{array}{c}\mathbf{P} \text { increase } \\
\text { Control }\end{array}$ & over & $\begin{array}{l}\mathbf{P} \text { requirement factor } \\
\text { (Pf) }\end{array}$ \\
\cline { 2 - 3 } 0 & Range & 13.6 & & \\
10 & $11.2-15.9$ & 14.3 & 0.7 & 14.3 \\
20 & $13.9-17.9$ & 15.9 & 2.3 & 8.7 \\
30 & $12.7-19.7$ & 16.4 & 2.8 & 10.7 \\
40 & $12.4-21.6$ & 16.8 & 2.4 & 16.7 \\
\hline Average & & & $\mathbf{1 2 . 6}$ \\
\hline
\end{tabular}

The relationship between relative grain yield response and soil $\mathrm{P}$ measured with the Olsen method is shown in the figure1. The critical $\mathrm{P}$ concentration $\left(P_{C}\right)$ was determined from the scatter diagram drawn using relative grain yields of tef and the corresponding soil test $\mathrm{P}$ values for all $\mathrm{P}$ levels $\left(0-40 \mathrm{~kg} \mathrm{ha}^{-1}\right)$. The $P c$ defined by the Cate- Nelson method in this study was about $15.6 \mathrm{mg} \mathrm{P} \mathrm{Kg}^{-1}$, with mean relative grain yield response of about $75 \%$ (Figure 1).

When the soil test value is below the critical level additional information is needed on the quantity of $\mathrm{P}$ required to elevate the soil $\mathrm{P}$ to the required level. This is the $\mathrm{P}$ requirement factor $(P f)$, the amount of $\mathrm{P}$ required to raise the soil test $\mathrm{P}$ by $1 \mathrm{mg} \mathrm{kg}^{-1}$, computed from the difference between available soil test $\mathrm{P}$ values from plots that received $0-40 \mathrm{~kg} \mathrm{P} \mathrm{ha}^{-1}$ using the second formula mentioned above. Accordingly the calculated $P f$ were 8.7 -16.7 and the overall average $P f$ of all treatments for the study area were 12.6 (table 2 ). Thus the rate of $P$ fertilizer required per ha can be calculated using the soil critical $\mathrm{P}$ concentration and the $\mathrm{P}$ requirement factor as indicated above in the third formula.

\section{DISCUSSION}

Availability of nutrients to crops is a function of the soil, crop, environment, and management; their interactions affects fertilizer use efficiency and the crop growth condition [21]. These factors need to be considered when using methods to calibrate soil- test nutrient values with relative grain yields. According to [31]low nutrient uptake of early in a plant's growth lowers nutrient quantity for the seed affecting yield.

According to the Cate- Nelson method, the critical levels of Olsen method P in the top $20 \mathrm{~cm}$ of soil about $15.6 \mathrm{mg} \mathrm{kg}^{-1}$; at values of greater than or equal to $15.6 \mathrm{mg} \mathrm{kg}^{-1}$, the crop achieved about $80 \%$ of its maximal yield in the absence of $\mathrm{P}$ fertilizer application (figure 1). This implies that $\mathrm{P}$ fertilizer application could be recommended for a build-up of the soil $\mathrm{P}$ to this critical value, or maintaining the soil $\mathrm{P}$ at this level. Increasing $\mathrm{P}$ beyond this level, the cost of additional $\mathrm{P}$ fertilizer to produce extra yield would likely be greater than the value of additional yield. Thus, in soils with available $P$ status below $15.6 \mathrm{mg} \mathrm{kg}^{-1}$, yield of tef could show a significant response to applications of $\mathrm{P}$ fertilizers. Whereas in areas with available $\mathrm{P}$ status greater than $15.6 \mathrm{mg} \mathrm{kg}^{-1}$, the $\mathrm{P}$ concentration in the soil exceeds crop needs so that further addition of $\mathrm{P}$ fertilizer may not result in a profitable yield increase. [32] reported a critical concentration of $13 \mathrm{mg} \mathrm{P} \mathrm{kg}^{-1}$ for corn response within this category (13-20 mg P kg-1) may be considered small, and maintenance fertilization can be recommended based on expected nutrient removal with harvest.

According to the result of our study, some yield response sites to $\mathrm{P}$ fertilizer applications had soil test levels above the critical level. Hence, to protect a potential loss of tef yield, at least a maintenance application of $15.6 \mathrm{~kg}$ $\mathrm{P} \mathrm{ha}^{-1}$ may be required depending on the tef yield goal and profitability. [32] also showed that soils testing 43 to $96 \mathrm{mg} \mathrm{P} \mathrm{kg}{ }^{-1}$ needed 10 to 20 years of cropping without $\mathrm{P}$ fertilization before yield response to $\mathrm{P}$ was observed. When soil test $\mathrm{P} \leq 20 \mathrm{mg} \mathrm{P} \mathrm{kg}^{-1}$, maize responded to annual $\mathrm{P}$ fertilization 50 to $75 \%$ of the time and did not respond at higher soil test $\mathrm{P}$ levels. Overall, to develop a valid soil test phosphorous recommendations for wider applicability using low, medium and high categories, several years of research is required to generate sufficient information for the most important crop- soil system [33].

Phosphorus fertilizer application at optimum level is necessary to improve yield of tef and protect from lodge, So that using our results, $\mathrm{P}$ fertilizer recommendations can be made for vertisols in the central Ethiopian highlands using an initial soil Olsen method phosphorus concentration target of phosphorus value (15.6mg kg-1) critical phosphorus bounded by minimum and maximum recommended rates. Finally in the absence of a soil test, a recommendation of $30 \mathrm{~kg} \mathrm{P} \mathrm{ha}^{-1}$ relatively which give the best response overall.

\section{CONCLUSION}

Soil-test P fertilizer calibration for tef on vertisols was proposed based on the Olsen method extraction. This calibration is based on the analysis of five different P-rate test site in which crop response to P fertilizer was determined. The results of this field work clearly indicated the importance of soil test based $\mathrm{P}$ fertilizer application on achieving maximum yield and yield components of tef under field conditions of West Shewa on vertisols soil type. In this part of the country, soil fertility depletion is severe and use of external input is very low. The critical available soil $\mathrm{P}$ concentration $\left(15.6 \mathrm{mg} \mathrm{kg}^{-1}\right)$ in Olsen method and the average P requirement factor (12.6) on 
vertisols have been established for the study sites and similar areas. The results seem promising and could be used as a basis for soil test $\mathrm{P}$ fertilizer recommendations for the production of tef on vertisols areas of central Ethiopian highlands. They can also be used for future intensification in the other areas for developing a system for soil test based fertilizer recommendation. Nevertheless, to develop an effective guideline for wider applicability of soil test based fertilizer recommendations, additional research assisted by appropriate soil $\mathrm{P}$ extraction method is required to generate sufficient information for the most important crop-soil systems.

\section{ACKNOWLEDGEMENTS}

The authors acknowledge the Ethiopian Institute of Agricultural Research (EIAR) and would like to express their appreciation to Mr. Haile Beza, Mr. Beyene Offa, Mr. Tesfaye Negash, Mrs. Kessach Birhanu, and Mrs.Tigist Feyisa for their technical assistance during the execution of the experiments under field condition. Appreciation is also due for the services of the analytical soil laboratory of Holeta Agricultural Research Centre.

\section{Conflict of Interest}

No conflict of interest.

\section{REFERENCES}

1. Mamo Tekalign, Richter, C., Heiligtag, B. (2002). Phosphorus availability studies on ten Ethiopian Vertisols. JARTS. 103:177-83.

2. Henao, J., and Baanante, C., (2006). Agricultural Production and Soil Nutrient Mining in Africa Implications for Resource Conservation and Policy Development: Summary an International Centre for Soil Fertility and Agricultural Development; IFDC.

3. Nkonya, E., Anderson, W., Kato, E., Koo, J., Mirzabaev, A., von Braun, J. and Meyer, S. (2016).Global cost of land degradation. In: Nkonya, E., Mirzabaev, A. and von Braun, J (eds). Economics of Land Degradation and Improvement. Springer, Netherlands.

4. Elias Eyasu, Okumu, O., Morse, S., Beshaw DGR (2000) .Nitrogen and phosphorus balance of Kindo-Koisha farms in southern Ethiopia. AgricEcosyst Environ 71: 93-113.

5. EthioSIS (Ethiopian Soil Information System). 2015. http://www.ata.gov.et/highlighted-deliverables/ethiopiansoil-information-system-ethiosis/. Accessed 15 March 2015.

6. Tamene Luliseged, Amede Tilahun, Kihara, J., Tibebe Degefie, Schulz, S. (2017). A review of soil fertility management and crop response to fertilizer application in Ethiopia: Addis Ababa, Ethiopia. 86 p. Available at: http://hdl.handle.net/10568/8299 Africa

7. Spaenij, D. L., Kooy, W. Y., and Koning, F. (2005). The Ethiopian cereal tef in celiac disease. New England Journal of Medicine 353, 1748-1749.

8. CSA (Central Statistical Agency) (2018) Report on: Area and Production of Major Crops (Private Peasant Holdings, Meher Season) Statistical Bulletin, 532, Addis Ababa, Ethiopia.

9. Ketema Seifu. (1993) .Tef (Eragrosits tef), Breeding, agronomy, genetic resources, utilization and role in Ethiopian agriculture. Institute of Agricultural Research.

10. National Soil Service (1994). Training materials on Soils for Use by development personnel. Watershed Development and Land Use Department MONRDEP, Addis Ababa, Ethiopia.

11. Negassa Wakene, Abera Yiferu. (2013). Soil Fertility Management Studies on Teff. In: Assefa Kebebew, Chanyalew Solomon, Tadele Zerihun. (eds.) Achievements and Prospects of Tef Improvement, and University of Bern, Switzerland.

12. IFPRI (International Food Policy Research Institute) (2010) Report on Fertilizer and Soil Fertility Potential in Ethiopia: Constraints and opportunities for enhancing the system.

13. Endale Kefyalew. (2011). Fertilizer Consumption and Agricultural Productivity in Ethiopia. Ethiopian Development Research Institute, Addis Ababa, Ethiopia.

14. David, M. E, and David, J. T. (2012). Modeling an Improvement in phosphorous utilization in Tropical Agriculture. Journal of Sustainable Agriculture, 36: 18-35.

15. Mamo Tekalign, Astatke Abiye, Srivastava, K. L. and Dibabe Asgelil. (1993);Improved Management of Vertisols for sustainable crop-livestock production in the Ethiopian Highlands; Synthesis report 1986-1992; Technical Committee of the Joint Vertisol Management Project, Addis Ababa, Ethiopia.

16. Dibabe Asgelil, Bekele Taye and Assen Yesuf. (2007).The status of micronutrients in Nitisols, Vertisols, Cambisols and Fluvisols in major Maize, Wheat, Teff and Citrus growing areas of Ethiopia. In "Proceedings of the Workshop on Status of Micronutrients", pp. 77-96, Addis Ababa, Ethiopia.

17. Evans, C.E., 1987. Soil test calibration. Soil testing, sampling, correlation, calibration and interpretation. Soil Science Society of America, SSSA special publication no. 21, USA.

18. McKenizie, R.H., and Kryzanowski, L. (1997). "Soil testing methods calibrated to phosphate fertilizer trials." Better Crops 81: 17-19. 
19. Muir, J. H. and Hedge, J. A. (2002). "Corn response to phosphorous and potassium fertilization at different soil test levels.” In Arkansas Soil Fertility Stugies edited by N.A. Slaton, 490: 32-33. University of Arkansas Agricultural Experiment Station Research Series.

20. Watson, M. and Mullen, R. (2007). "Understanding soil test for plant- available phosphorous." Ohio State University, USA.

21. Agegnehu Getachew., and Lakew Berahne. (2013). Soil test phosphorous calibration for malt barley production on Nitisols of Ethiopian highlands. Trop.Agric. 90: 177 -187.

22. Sahlemedhin Sertus and Taye Bekele (2007). Procedure for soil and plant analysis Technical Bulletin No.74.National Soil Research Center, Ethiopian Agricultural Organization, Addis Ababa, Ethiopia.

23. Carter, M.R. (Ed.), 1993. Soil sampling and methods of analysis. Canadian Soil Science.

24. Walkley, A. and Black, C. A. (1934). Determination of organic matter in the soil by chromic acid digestion. Soil Sci., 63: 251-264.

25. Jackson, M.L., 1958. Soil Chemical Analysis, Prentice Hall Inc., Engle Wood Cliffs, New Jersey, pp: 183204.Bray, H. R. and Kurtz, L. T. (1945). Determination of total organic and available forms of phosphorus in soils; Soil Sci.; 9:39-46

26. Bray, R.H. and Kurtz, L.T. 1945. Determination of total organic and available phosphorus in soils. Soil Science, 1945.59:39-45.

27. SAS Institute, 2002. SAS User's Guide, Statistics version 9.0 (Ed.). SAS Inst., Cary, NC, USA. Rome.

28. Dahnke, W.C. and Olsen, R. A. (1990). Soil test correlation, calibration, and recommendation. P 45-71. In: R.L. Westerman(ed.) soil testing and plant analysis, $3^{\text {rd }}$ ed., SSSA Book Series: 3, Soil science society of America, Madison, WI.

29. Nelson, L.A., and Anderson, R.L (1977). Partitioning soil test-crop response probability. In Soil testing: Correlating and interpreting the analytical results, ed. T. R. Peck. Madison, WI: American Society of Agronomy pp. 19-39.

30. Kumbhar, D. D., Pharande, K. S. and Daftardar, S. Y. (1988). Soil phosphorus fractions in Vertisols as influenced by fertility gradients and yield targets for mungbean-sorghum sequential crops. In : Phosphorus in Indian Vertisols - Summary proceedings of a workshop, 23-26 Aug 1988, ICRISAT centre, Patancheru (India), p. 36.

31. Jones, C., Olson-Rutz, K., Dinkins C.P., (2011). Nutrirent uptake Timing by Crops: to assist with fertilizing decisions. Montana State University. USA.

32. Mallarino, A. P. 2003. Field calibration for corn of the Mehlich-3 soil phosphrorus test with colorimetric and inductively coupled plasma emission spectroscopy determination methods. Soil Science Society America Journal 67: 1928-34. Doi: 10.2136/sssaj 2003.1928.

33. Agegnehu, G., Liben, M., Molla, A., Feyissa, A., Bekele, A., and F. Getaneh. 2011. Research achievements in soil fertility management in relation to barley in Ethiopia. In "Barley Research and Development in Ethiopia" (B. Mulatu and S. Grando, eds.), pp. 137-152. ICARDA, Addis Ababa, Ethiopia. 